\title{
Effect of cheese containing Lactobacillus delbrueckii subsp. Lactis CRL 581 on blood pressure in prehypertensive and stage 1 hypertensive subjects
}

\author{
Efecto de un queso con LactobacillusdelbrueckiisubspLactis CRL 581 \\ sobre la hipertensión arterial en individuos con prehipertensión o \\ estadio 1 de hipertensión arterial
}

\begin{abstract}
Hypertension is one of the main risk factors for cardiovascular disease. Functional foods containing bioactive peptides have been proposed as a strategy to decrease blood pressure $(B P)$ in subjects under no pharmacological treatment. The aim of this study was to compare the effect of low-sodium, low-fat (LSLF) cheese and LSLF cheese containing Lactobacillus delbrueckii subsp. lactis CRL 581 (LSLF581) on BP in pre-hypertensive and stage 1 hypertensive subjects. Sixty-one pre-hypertensive and stage 1 hypertensive subjects assigned to one of twos (LSLF, $n=29$ and LSLF581, $n=32$ ) participated in this 12-month prospective, randomized, double-blind, crossover trial. Twenty-four $h$ ambulatory BP monitoring was performed at the beginning and at the end of each four-week study period. Systolic and diastolic BP decreased in both study groups, but differences between groups were not significant (systolic, -1.78 and $-0.2 \mathrm{mmHg}$; diastolic, -1.54 and -0.42 $\mathrm{mmHg}$ in LSLF581 and LSLF, respectively). Although our results could not support a BP lowering effect of LSLF581, small BP reductions could favorably prevent cardiovascular disease development.

Keywords: Biopeptides; Cheese; Functional foods; Lactobacillus delbrueckii; Pre-hypertension.
\end{abstract}

\section{RESUMEN}

La hipertensión arterial es uno de los principales factores de riesgo de enfermedad cardiovascular. Los alimentos funcionales que contienen biopéptidos constituyen una estrategia útil para disminuir la presión arterial $(P A)$ en personas que no están bajo tratamiento farmacológico. El objetivo del estudio fue comparar el efecto de un queso bajo en sodio y bajo en grasas (BSBG) y el mismo queso con Lactobacillus delbrueckii subsp. lactis CRL 581 (BSBG581) sobre la PA en personas con prehipertensión y estadio 1 de hipertensión arterial. Realizamos un estudio prospectivo, randomizado, cruzado y doble ciego durante 12 meses en 61 personas con prehipertensión y estadio 1 de hipertensión arterial, asignadas a dos grupos: $B S B G(n=$ 29) y BSBG581 ( $n=32)$. Se realizó monitoreo ambulatorio de la PA (MAPA) durante $24 \mathrm{~h}$ al comienzo y al final de
Martín Salazar ${ }^{1}$, Agustina Malpeli ${ }^{*}$, Elvira Hebert ${ }^{3}$, Ricardo Cravero ${ }^{4}$, Walter Espeche ${ }^{1}$, Cecilia Leiva Sisnieguez ${ }^{\prime}$, Rodolfo N. Stavile', Carlos March ${ }^{1}$, Carlos Leiva Sisnieguez', Marina Tavella², Liliana Disalvo², Victoria Fasano ${ }^{2}$, Graciano Magrini ${ }^{4}$, Dimas Visentin ${ }^{4}$, M. Pía Taranto ${ }^{3}$, Horacio F. González

1. Unidad de Enfermedades Cardiometabólicas, Hospital Universitario San Martín, La Plata, Argentina. 2. Instituto de Desarrollo e Investigaciones Pediátricas "Prof. Dr. Fernando E Viteri", Hospital de Niños de La Plata, Comisión de Investigaciones Científicas - Provincia de Buenos Aires, Argentina.

3. Centro de Referencia para Lactobacilos, Consejo Nacional de Investigaciones Científicas y Técnicas, Tucumán, Argentina. 4. Departamento de Investigación, Innovación y Desarrollo, Sancor CUL, Sunchales, Santa Fe, Argentina.

*Corresponding author: Agustina Malpeli, IDIP-Instituto de Desarrollo e Investigaciones Pediátricas "Prof. Dr. Fernando E. Viteri", Calle 63 N ${ }^{\circ} 1069,1900$ La Plata, Argentina. E-mail: agustinamalpeli74@gmail.com

Este trabajo fue recibido el 06 de julio de 2018. Aceptado con modificaciones: 20 de diciembre de 2018. Aceptado para ser publicado: 06 de agosto de 2019.

cada etapa del estudio (cuatro semanas).La PA sistólica y diastólica disminuyó en ambos grupos, aunque las diferencias entre grupos no fueron significativas (sistólica, -1.78 y $-0.2 \mathrm{mmHg}$; diastólica -1.54 y $-0.42 \mathrm{mmHg}$ en BSBG581 y $B S B G$ respectivamente). Aunque nuestros resultados no pueden confirmar el efecto hipotensor del queso BSBG581, las reducciones moderadas de la PA podrían prevenir el desarrollo de enfermedad cardiovascular.

Palabras clave: Alimentos funcionales; Biopéptidos; Lactobacillusdelbrueckii; Prehipertensión; Queso.

\section{INTRODUCTION}

Hypertension is defined as a systolic blood pressure (SBP) of $140 \mathrm{mmHg}$ or more, and a diastolic blood pressure 
(DBP) of $90 \mathrm{mmHg}$ or more. Currently, it is one of the main risk factors for cardiovascular disease (CVD) and the high associated mortality rate worldwide ${ }^{1,2}$.

The Seventh Report of the Joint National Committee on Prevention, Detection, Evaluation, and Treatment of High Blood Pressure (JNC 7) defines prehypertension as SBP between 120-139 $\mathrm{mmHg}$ and DBP between 80-89 $\mathrm{mmHg}^{3}$. Subjects with high-normal BP (SBP, 130-139 $\mathrm{mmHg}$; DBP, $85-89 \mathrm{mmHg}^{3}$ may become hypertensive in relatively short periods of time ${ }^{4}$, thereby presenting higher risk of CVD morbidity and mortality ${ }^{5}$.

The pharmacological treatment of prehypertension or high-normal BP subjects does not ensure long-term morbidity and mortality reduction ${ }^{6}$. Therefore, lifestyle changes are the main treatment strategy in these subjects. Additionally, stage 1 hypertensive subjects (SBP 140-159 and DBP 90-99 $\mathrm{mmHg}$ ) with no signs of target organ lesion, multiple CV risk factors or diabetes may also be treated only with lifestyle changes ${ }^{7}$.

Among treatment interventions, different diets can help lower $\mathrm{BP}^{8,9}$. This is the case of low-fat dairy products, probably because they contain calcium, magnesium, potassium and vitamin $\mathrm{D}^{10,11,12,13,14,15}$. However, dairy products containing bioactive peptides obtained by enzymatic proteolysis would provide an alternative choice $^{16,17,18,19}$. A synergistic protective effect would be exerted by micronutrients in dairy products and bioactive peptides.

Proteolysis is the main event during cheese ripening, starting with initial lysis of casein by coagulants and proteases present in milk. A second proteolysis occurs by action of proteases and peptidases of lactic acid bacteria, which is used as starter culture with proteolytic activity ${ }^{18}$.

It has been reported that some strains of Streptococcusthermophilus, Lactobacillushelveticus, Lactobacillusdelbrueckii subsp. bulgaricus and Lactobacillusdelbrueckii subsp. lactis may release bioactive peptides with angiotensin I-converting enzyme (ACE) inhibitory activity ${ }^{20,21,22,23,24}$. Ile-Pro-Pro (IPP) and ValPro-Pro (VPP) are two casein-derived peptides known to lower $\mathrm{BP}^{18,25,26}$. These bioactive peptides are released by different strains and may be used in the formulation of functional foods and nutraceuticals, representing a healthier and natural alternative for regulating BP.

Several antihypertensive peptides, including IPP and VPP, have been recently characterized after $\alpha$ and $\beta$ casein hydrolysis by L.delbrueckii subsp.lactis CRL $581^{22,27}$. However, the effect of L.delbrueckii subsp.lactis CRL 581 on BP has not been demonstrated in human clinical trials.

The aim of this study was to compare the effect of consuming low-sodium, low-fat cheese and the same cheese containing a strain with functional properties as L. delbrueckii subsp. lactis CRL 581, on BP in subjects with prehypertension and stage 1 hypertension without pharmacological treatment or indication of such a treatment.

\section{SUBJECTS AND METHODS \\ Study design}

The study was a randomized, double-blind, crossover trial performed in subjects with prehypertension and stage 1 hypertension according to the JNC 7 classification (SBP, 120-159 mmHg and DBP, 80-99 $\mathrm{mmHg}$ ), without antihypertensive drug treatment ${ }^{3}$.

\section{Participants}

Participants were recruited from the Cardiometabolic Disease Unit of San Martin University Hospital, La Plata, Argentina, between July 2015 and July 2016. From a total of 350 patients attending the Unit, 82 were assessed for eligibility and included in the study protocol (Figure 1). We restricted the study population to subjects with the above-mentioned BP values because they did not have indication for antihypertensive drug treatment in the shortterm according to the current guidelines, and because a trial based on lifestyle modifications is an acceptable therapeutic approach.

Structured interviews were conducted during office visits a week before participant allocation to the interventions. Three BP measurements at 1-min intervals were taken by specially trained nurses after a 15-min rest period, using OMRON HEM 705 CP devices (OMRON HEALTHCARE Co., Kyoto, Japan). Exclusion criteria were hypertension, evidence for target organ lesion, diabetes, pregnancy, prior or current treatment with an antihypertensive agent for any indication, or any abnormal laboratory determination. At initial evaluation, fasting blood samples were drawn for creatinine, glucose, uric acid and lipid profile assessment.

After this initial evaluation, 61 individuals were selected and assigned by random allocation (EPIDAT 3.1; 1:1 allocation ratio) to one of two groups: low-sodium, low-fat cheese (LSLF, $\mathrm{n}=29$ ) and LSLF with $L$. delbrueckii subsp. Lactis CRL 581 (LSLF581, $\mathrm{n}=32$ ). Participants consumed $100 \mathrm{~g} /$ day of the corresponding cheese during four weeks, followed by a four-week washout period and a final four-week crossover.

As already mentioned, patients from the Cardiometabolic Disease Unit diagnosed with prehypertension or stage 1 hypertension did not receive antihypertensive drugs. Instead, they were advised regarding different lifestyle changes they should make, such as dietary sodium reduction, but they were not followed-up.

\section{BP assessment}

BP testing was performed in all patients who accepted participation in the study at each of the four office visits. Primary testing was the mean of all recordings in the 24-h ambulatory BP monitoring (ABPM). At the beginning and at the end of each of the four-week treatment periods, ABPM was performed with a SpaceLabs 90207 monitor (Spacelabs Healthcare, Issaquah, WA, USA) programmed to read $\mathrm{BP}$ at intervals of 20 min during the day and 30 min at night. Day-time and night-time record intervals 


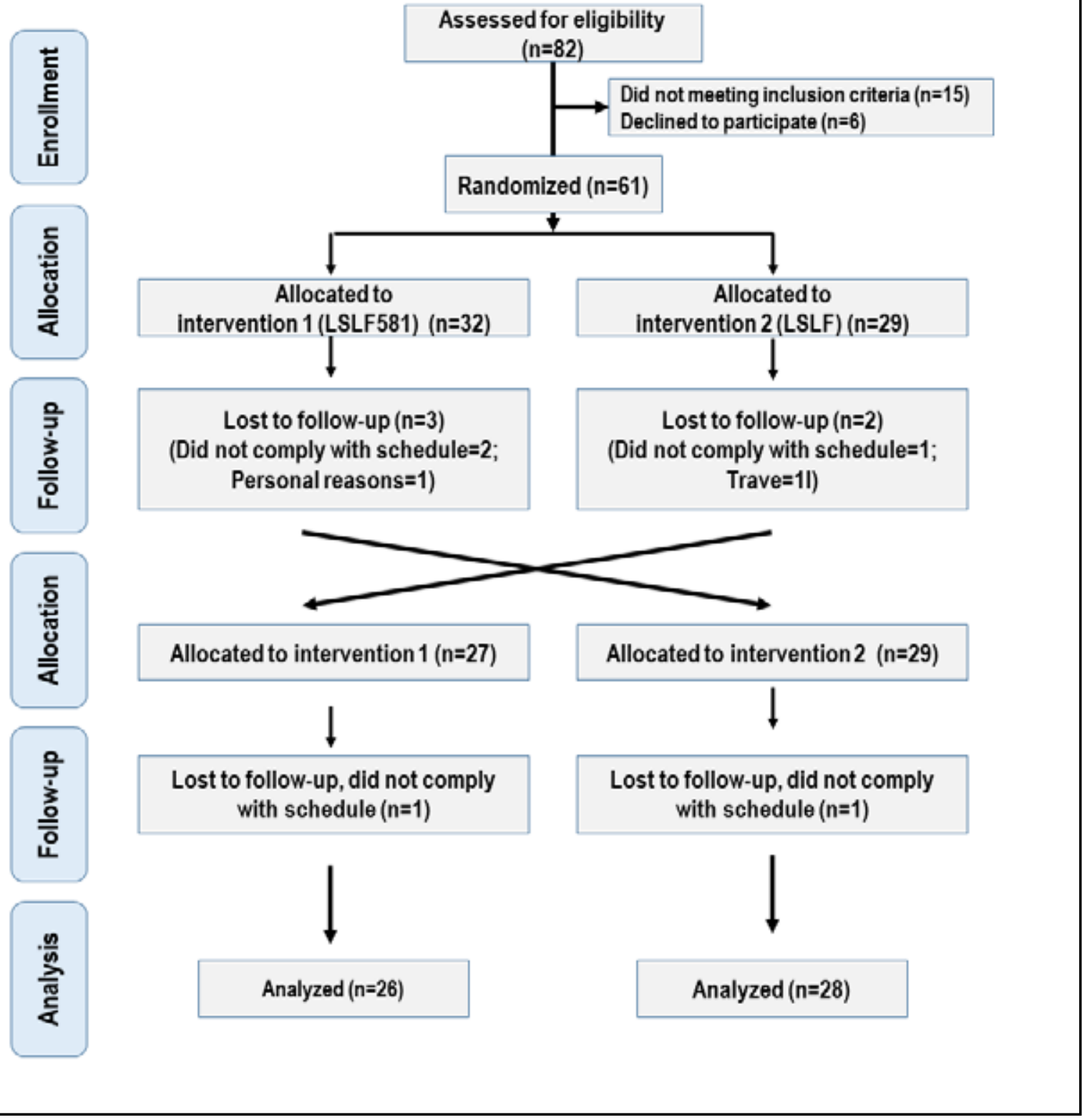

Figure 1: Flow chart for the study design.

were defined according to the information recorded in the patient's diary. Mean 24-h SBP and DBP values and mean day and night readings were compared at the beginning and at the end of each study period.

\section{Anthropometric measurements}

Anthropometric assessments were performed at the beginning and at the end of the study while subjects were wearing light-weight clothing provided by the institution, with shoes removed. Body mass index was calculated by dividing the weight in kilograms by the square of the height in meters. Waist circumference was measured in centimeters midway between the costal margin and the iliac crest at the end of a normal expiration.

\section{Cheese characteristics}

Cheese was processed with the same coagulant and Strthermophilus as commercial fermenting agent. Both cheeses had the same nutritional composition (Table 1) and low-fat, low-sodium content, but one of them 
contained the strain L.delbrueckii subsp. lactis CRL 58121 obtained from the CERELA culture collection (San Miguel de Tucumán, Argentina). Both LSLF and LSLF581 were packaged in 500-g average weight units.

ACE-inhibitory activity of peptides was determined in both LSLF and LSLF581samples according to the technique described by Villegas et al. ${ }^{22}$. The relative percent ACE-inhibition at $0,15,30$ and 60 days of maturation was $13,24,37$ and $35 \%$, respectively; the enzyme showed higher activity in LSLF581 since time 0. Since cheese is a fermented milk product, both cheeses presented proteolysis, which could lead to the generation of bioactive peptides with anti-ACE activity. Therefore, the absolute values of inhibition would be greater than those shown as relative values.

The potential BP lowering effect of LSLF581 demonstrated by in vitro assays was maintained during storage.

\section{Statistical analyses}

Quantitative variables are presented as means \pm standard deviations and qualitative variables are presented as percentages. Quantitative variables were tested for normality with Kolmogorov-Smirnov with Lilliefors correction, showing a normal distribution. The analysis of variance for repeated measures was used to determine differences over time and to compare the study groups. Before-after differences in SBP and DBP within groups were assessed with paired Student's t-test. $P$ values $<0.05$ were considered statistically significant. Data were analyzed using SPSS version 19 for Windows.

\section{Ethical considerations}

All subjects provided written informed consent after performing a face-to-face interview with the staff responsible, during which normal BP values and risks of hypertension were discussed. The study design and consent forms were approved by the Joint Health Research Committee of the Ministry of Health of the Province of Buenos Aires (file No 2919/883/14). The principal investigator and study staff responsible for patient contact were blinded to cheese assignment.

\section{RESULTS}

From a total of 61 subjects enrolled, three abandoned the LSLF group and four abandoned the LSLF581 group (Figure 1). None of the subjects presented any side effects. Baseline characteristics of participants are listed in table 2.

Table 3 shows the effect of consuming both cheeses on SBP and DBP. In the LSLF581 group, SBP and DBP were reduced by more than $1 \mathrm{mmHg}$; the highest decrease was observed in night SBP $(-2.53 \mathrm{mmHg})$. However, differences between groups were not significant.

The assessment of each group separately (before and after, Student's t-test) showed that subjects in the LSLF581group significantly decreased night SBP $(p=0.022)$
Table 1. Chemical composition of 100-g low-sodium, lowfat (LSLF) cheese and LSLF cheese containing L. delbrueckii subsp. lactis CRL 581 (LSLF581).

\begin{tabular}{|lc|}
\hline Energetic value (Kcal/Kj) & 208 / 874 \\
Proteins $(\mathrm{g})$ & 25 \\
Total fat $(\mathrm{g})$ & 12 \\
Saturated fat $(\mathrm{g})$ & 7.7 \\
Monounsaturated fat $(\mathrm{g})$ & 3.1 \\
Polyunsaturated fat $(\mathrm{g})$ & 0.5 \\
Cholesterol $(\mathrm{mg})$ & 36 \\
Sodium $(\mathrm{mg})$ & 200 \\
Calcium $(\mathrm{mg})$ & 700 \\
\hline
\end{tabular}

Table 2. Baseline characteristics of participants.

\begin{tabular}{|c|c|c|}
\hline & Mean $( \pm \mathrm{SD})$ & n (\%) \\
\hline Age (years) & $47 \pm 13.7$ & \\
\hline Female & & $34(62)$ \\
\hline Smokers & & $5(9)$ \\
\hline $\mathrm{BMI}\left(\mathrm{kg} / \mathrm{m}^{2}\right)$ & $29.3(4.72)$ & \\
\hline WC (cm) & $96.5(11.17)$ & \\
\hline SBP at doctor's office (mm Hg) & $130(11.6)$ & \\
\hline DBP at doctor's office ( $\mathrm{mm} \mathrm{Hg}$ ) & $82(9.0)$ & \\
\hline Creatinine (mg/dL) & $0.82(0.16)$ & \\
\hline Blood glucose $(\mathrm{g} / \mathrm{L})$ & $0.95(0.10)$ & \\
\hline Cholesterol (g/L) & $1.98(0.31)$ & \\
\hline HDL-Chol (g/L) & $0.43(0.09)$ & \\
\hline LDL-Chol (g/L) & $1.31(0.28)$ & \\
\hline Triglycerides (g/L) & $1.24(0.52)$ & \\
\hline
\end{tabular}

BMI: body mass index; WC: waist circumference; SBP: systolic blood pressure; DBP: diastolic blood pressure; HDL-Chol: highdensity lipoprotein cholesterol; LDL-Chol: low-density lipoprotein cholesterol.

\section{DISCUSSION}

In our study, the intake of 100-gLSLF581 cheese did not have BP lowering effect on adult prehypertension or stage 1 hypertension among patients without pharmacological treatment.

Food strategies to prevent and reduce hypertension, such as the DASH diet, the Mediterranean diet or the Nordic diet, include low-fat dairy products ${ }^{8,9}$. For instance, consumption of low-fat milk, yogurt and cheese significantly decrease SBP but not $\mathrm{DBP}^{15}$, as compared with the intake of fruits without dairy products ${ }^{13}$. Crichton et al. ${ }^{28}$ suggest that arterial stiffness and SBP could be prevented by the consumption of dairy products after adjusting for demographic, cardiovascular and dietary factors. 
Table 3. Changes in SBP and DBP (ABPM) in the LSLF and LSLF581 groups.

\begin{tabular}{|c|c|c|c|c|c|c|}
\hline & & $\begin{array}{c}\text { LSLF } \\
\text { Mean (SD) }\end{array}$ & Diff. & $\begin{array}{l}\text { LSLF581 } \\
\text { Mean (SD) }\end{array}$ & Diff. & $\mathbf{P}$ \\
\hline \multirow[t]{2}{*}{$24-h$} & baseline & $125.9(7.9)$ & -0.2 & $126.6(8.8)$ & -1.7 & 0.950 \\
\hline & final & 125.7 (8.6) & & $124.9(9.1)$ & & \\
\hline \multirow[t]{2}{*}{ Day-time } & baseline & $130.4(7.8)$ & 0.4 & 130.9 (8.9) & -1.0 & 0.778 \\
\hline & final & $130.8(9.0)$ & & 129.9 (9.8) & & \\
\hline \multirow[t]{2}{*}{ Night-time } & baseline & $115.8(9.5)$ & -0.8 & $115.8(9.0)$ & $-2.5^{*}$ & 0.337 \\
\hline & final & $115.0(9.9)$ & & $113.3(10.0)$ & & \\
\hline \multicolumn{7}{|c|}{ DBP (ABMP) } \\
\hline \multirow[t]{2}{*}{$24-h$} & baseline & $78.4(7.3)$ & -0.4 & $79.1(8.2)$ & -1.5 & 0.828 \\
\hline & final & $78.0(7.1)$ & & $77.6(7.3)$ & & \\
\hline \multirow[t]{2}{*}{ Daytime } & baseline & $82.6(7.3)$ & 0.3 & $84.8(8.4)$ & -1.3 & 0.456 \\
\hline & final & $82.9(7.4)$ & & $82.5(7.8)$ & & \\
\hline \multirow[t]{2}{*}{ Nighttime } & baseline & $69.0(8.7)$ & -0.9 & $68.4(7.4)$ & -1.5 & 0.142 \\
\hline & final & 68.1 (7.8) & & $66.9(7.2)$ & & \\
\hline
\end{tabular}

DBP: diastolic blood pressure; SBP: systolic blood pressure; ABMP: ambulatory blood pressure monitoring; LSLF: low-sodium, low-fat; LSLF581: LSLF containing L. delbrueckii subsp. lactis CRL 581.

* Before and after, Student's t-test, $\mathrm{p}=0.022$

On the other hand, the use of lactotripeptides (LTP) in healthy diets has also been suggested for their safe and effective BP lowering effect ${ }^{29}$. Different reports have shown the effect of casein-derived LTP(VPP, IPP) on SBP and $\mathrm{DBP}^{18},{ }^{25,26}$ while other studies could not demonstrate such effect ${ }^{30,31,32}$. In our study, we chose a low fat cheese matrix to assess the possible effect of LTP on BP in a sample of Argentinean subjects with prehypertension or stage 1 hypertension.

A recent meta-analysis about changes reported in 30 trials shows significant reductions in SBP $(-2.95 \mathrm{mmHg})$ and DBP $(-1.51 \mathrm{mmHg})$ measured at the doctor's office ${ }^{33}$. However, when BP was analyzed by ABPM, no significant changes could be detected and reductions in both SBP and DBP were lower than $1 \mathrm{mmHg}$. Remarkably, ABPM is an accepted method of BP measurement in hypertension trials because it is more reproducible than office $\mathrm{BP}$ measurements, does not show a placebo effect and excludes white-coat hypertensive people. Despite discrepancies between ABPM- and office-based measurement studies, researchers are aware of ABPM advantages, and its use in hypertension trials is consequently increasing ${ }^{34,35}$.

The matrix used as LTP vehicle in the trials evaluated in the above mentioned meta-analysis was fermented milk, yogurt, fruit juice and tablets, but not cheese ${ }^{33}$. A study carried out in Norway analyzing the effect of Gamalost, a typical Norwegian low-fat (1\%) and high-protein (50\%) cheese found no significant differences in SBP and DBP reductions, regardless of the frequency of Gamalost intake ${ }^{36}$. Despite differences in chemical composition and frequency of intake between the Norwegian cheese and the one tested in our study, we could not find significant BP reductions with our LSLF581 cheese.

Although the effect of LSLF581 on BP could not be currently demonstrated, the trend observed in the beforeafter comparison might be confirmed with a larger sample size. Regarding diet, despite participants were asked to consume low-sodium food, they could not be completely followed-up and sodium intake could not be quantified. On the other hand, our findings are the first reported in our country showing that neither LSLF nor LSLF581 increased BP among subjects with prehypertension or stage 1 hypertension; therefore, we suggest that their consumption would be safe for these patients. Furthermore, ABMP proved to be accurate to assess changes in $\mathrm{BP}^{34,35}$. Thus, although we could not detect significant $\mathrm{BP}$ reductions between the study groups, small BP drops could favorably prevent CVD development ${ }^{37,38}$. 
Acknowledgments: This study was funded by FONARSEC (Fondo Argentino Sectorial), Ministerio de Ciencia, Tecnología e Innovación Productiva (id:SGP:02), Argentina. The authors would like to thank Susana Cor for BP measurements, Natalia Alvarez for blood extractions, Andrea Touza for product handling and administration, and Adriana Di Maggio for manuscript correction and edition.

Conflict of interests. The authors declare that they have no conflict of interests.

Author contributions. All authors contributed to the implementation of the study. R.N.S., A.M. and H.F.G. participated in protocol design, data analysis, discussion of results and final review. L.D. performed biochemical determinations. V.F. performed the statistical analysis of data. E.H. and M.P.T. developed the strain, analyzed ACEinhibitory activity, discussed and revised the final version of the manuscript. R.C., G.M. and D.V. developed the cheeses and analyzed ACE-inhibitory activity. W.E., C.L-S.,M.S., C.M. and C.L-S evaluated subjects at enrolment, performed and analyzed ABPM.M.T., C.L-S. and A.M. coordinated and followed the project and were in charge of cheese delivery.

\section{REFERENCES}

1. Stamler J, Stamler R, Neaton JD. Blood pressure, systolic and diastolic, and cardiovascular risks. US population data. Arch Intern Med 1993; 153: 598-615.

2. World Health Organization. Global status report on noncommunicable diseases 2004. 2004; Geneva: WHO.

3. Seventh Report of the Joint National Committee on Prevention, Detection, Evaluation, and Treatment of High Blood Pressure. Hypertension 2003; 42: 1206-1252.

4. Carbajal HA, Salazar MR, Riondet B, Quaini SM, Rechifort $V E$, Rodrigo HF, et al. Ten-year blood pressure trends in nonhypertensive inhabitants of La Plata, Argentina. Can J Cardiol 1998; 14: 917-922.

5. Salazar MR, Espeche WG, Aizpurua M, Leiva Sisnieguez BC, Leiva Sisnieguez CD, Dulbecco CA, et al. Risk of cardiovascular disease according to blood pressure categories in an Argentinian cohort. Rev FacCien Med Univ Nac Cordoba 2016; 73: 181187.

6. Zhang Y, Lee ET, Devereux RB, Yeh J, Best LG, Fabsitz RR, et al. Prehypertension, diabetes, and cardiovascular disease risk in a population-based sample: The Strong Heart Study. Hypertension 2006; 47: 410-414.

7. European Society of Hypertension-European Society of Cardiology Guidelines Committee. 2003 European Society of Hypertension-European Society of Cardiology guidelines for the management of arterial hypertension. J Hypertens. 2003; 21: 1011-1053.

8. Gay HC, Rao SG, Vaccarino V, Ali MK. Effects of different dietary interventions on blood pressure:Systematic review and meta-analysis of randomized controlled trials. Hypertension. 2016; 67: 733-739.

9. Ndanuko RN, Tapsell LC, Charlton KE, Neale EP, Batterham MJ. Dietary patterns and blood pressure in adults: A systematic review and meta-analysis of randomized controlled trials. Adv Nutr 2016; 7: 76-89.
10. Drouin-Chartier JP, Gigleux I, Tremblay AJ, Poirier L, Lamarche $B$, Couture $P$. Impact of dairy consumption on essential hypertension: a clinical study. Nutr I 2014; 13: 83-92.

11. Wang $H$, Fox CS, Troy LM, Mckeown NM, Jacques PF. Longitudinal association of dairy consumption with the changes in blood pressure and the risk of incident hypertension: the Framingham Heart Study. Br J Nutr 2015; 114: 1887-1899.

12. Soedamah-Muthu SS, Verberne LDM, Ding EL, Engberink MF, Geleijnse JM. Dairy consumption and incidence of hypertension: a dose-response meta-analysis of prospective cohort studies. Hypertension 2012; 60: 1131-1137.

13. Machin DR, Park W, Alkatan M, Mouton M, Tanaka H. Hypotensive effects of solitary addition of conventional nonfat dairy products to the routine diet: a randomized controlled trial. Am J Clin Nutr 2014; 100: 80-87.

14. Kris-Etherton PM, Grieger JA, Hilpert KF, West SG. Milk products, dietary patterns and blood pressure management. J Am Coll Nutr 2009; 28(Suppl 1): 103S-119S.

15. McGrane MM, Essery E, Obbagy J, Lyon J, Macneil P, Spahn J, et al. Dairy consumption, blood pressure, and risk of hypertension: an evidence-based review of recent literature. Curr Cardiovasc Risk Rep 2011; 5: 287-298.

16. Pripp AH. Effect of peptides derived from food proteins on blood pressure: a meta-analysis of randomized controlled trials. Food Nutr Res 2008; 52: 10.3402/fnr.v52i0.1641.

17. Domínguez González KN, Cruz Guerrero AE, González Márquez H, Gómez Ruiz LC, García-Garibaya M, Rodríguez Serrano G. El efecto antihipertensivo de las leches fermentadas. Rev Argent Microbiol 2014; 46: 58-65.

18. Hebert EM, Saavedra L, Ferranti P. Bioactive peptides derived from casein and whey proteins. In: Biotechnology of Lactic Acid Bacteria: Novel Applications (F Mozzi, R Raya, G Vignolo, eds.).Ames: Wiley-Blackwell; 2010; p. 233-49.

19. Ahtesh FB, Stojanovska L, Apostolopoulos V. Antihypertensive peptides released from milk proteins by probiotics. Maturitas 2018, 115: 103-109.

20. Savijoki K, IngmerH, Varman P. Proteolytic systems of lactic acid bacteria. Appl Microbiol Biotechnol 2006; 71: 394-406.

21. Tsai J-S, Chen Y-J, Pan BS, Gong SD, Chung MY. Antihypertensive effect of bioactive peptides produced by protease-facilitated lactic acid fermentation of milk. Food Chemistry 2008; 106: 552-558.

22. Villegas JM, Picariello G, Mamone G, Espeche Turbay MB, Savoy de Gioriand G, Hebert EM. Milk-derived angiotensinI-converting enzyme inhibitory peptides generated by Lactobacillus delbrueckii subsp. lactis CRL 581. Peptidomics 2014; 1: 22-29.

23. Minervini F, Algaron F, Rizzello CG, Fox PF, Monnet $V$, Gobbetti M. Angiotensin I-converting-enzyme-inhibitory and antibacterial peptides from Lactobacillus helveticus PR4 proteinase-hydrolyzed caseins of milk from six species. Appl Environ Microbiol 2003; 69: 5297-5305.

24. Shakerian M, Razavi SH, Ziai SA, Khodaiyan F, Yarmand MS, Moayedi A. Proteolytic and ACE-inhibitory activities of probiotic yogurt containing non-viable bacteria as affected by different levels of fat, inulin and starter culture. I Food Sci Technol 2015; 52: 2428-2433.

25. Cicero AFG, Aubin F, Azais-Braesco V,Borghi C. Do the lactotripeptidesisoleucine-proline-proline and valineproline-proline reduce systolic blood pressure in European subjects? A meta-analysis of randomized controlled trials. Am J Hypertens 2013; 26: 442-449.

26. Qin $L Q, X u / Y$, Dong $J$, , Zhao $Y$, van Bladeren $P$, Zhang $W$. 
Lactotripeptides intake and blood pressure management: A meta-analysis of randomized controlled clinical trials. Nutr Metab Cardiovasc Dis 2013; 23: 395-402.

27. Hebert ME, Mamone G, Picariello G, Raya RR, Savoy G, Ferranti $P$, et al. Characterization of the pattern of $\alpha$ s1- and $\beta$ casein breakdown and release of a bioactive peptide by a cell envelope proteinase from Lactobacillus delbrueckiisubsp. lactis CRL 581. Appl Environ Microbiol 2008; 74: 3682-3689.

28. Crichton GE, Elias MF, Dore GA, Abhayaratna WP, Robbins MA. Relations between dairy food intake and arterial stiffness pulse wave velocity and pulse pressure. Hypertension. 2012; 59: 1044-1051.

29. Boelsma E,Kloek J. Lactotripeptides and antihypertensive effects: a critical review. Br J Nutr 2009; 101: 776-786.

30. Mizuno S, Matsuura K, Gotou T, Nishimura S, Kajimoto O, Yabune $M$, et al. Antihypertensive effect of casein hydrolysate in a placebo-controlled study in subjects with high-normal blood pressure and mild hypertension. Br J Nutr 2005; 94: 84-91.

31. Engberink MF, Schouten EG, Kok FJ, van Mierlo LA, Brouwer IA, Geleijnse IM. Lactotripeptides show no effect on human blood pressure results from a double-blind randomized controlled trial. Hypertension 2008; 51: 399-405.

32. Jauhiainen $T$, Niittynen L, Orešič $M$,Järvenpää $S$, Hiltunen
TP, Rönnback $M$, et al. Effects of long-term intake of lactotripeptides on cardiovascular risk factors in hypertensive subjects. Eur J ClinNutr 2012; 66: 843-849.

33. Fekete ÁA, Givens DI, Lovegrove JA. Casein-derived lactotripeptides reduce systolic and diastolic blood pressure in a meta-analysis of randomised clinical trials. Nutrients 2015; 7: 659-681.

34. Mansoor GA, White WB. Contribution of ambulatory blood pressure monitoring to the design and analysis of antihypertensive therapy trials. I Cardiovasc Risk 1994; 1: 136-142.

35. Mansoor GA. Ambulatory blood pressure monitoring in clinical trials in adults and children. Am J Hypertens 2002; 15(2 pt2): 385-425.

36. Nilsen R, Pripp AH, Høstmark AT, Haug A, Skeie S. Is consumption of a cheese rich in angiotensin-converting enzyme-inhibiting peptides, such as the Norwegian cheese Gamalost, associated with reduced blood pressure? I Dairy Sci 2014; 97: 2662-2668.

37. Cook NR, Cohen J, Hebert PR,Taylor JO, Hennekens CH. Implications of small reductions in diastolic blood pressure for primary prevention. Arch Intern Med 1995; 155: 701-709.

38. Stamler J.The INTERSALT Study: background, methods, findings, and implications. Am J ClinNutr 1997; 65: 626S-642S. 